Despite this difficulty, King's anthology could prove very useful in sparking debate between students of the Reformation. It is a good supplement to a historiographical study of Reformation thought, because it shows that the people involved in the great religious upheaval of the early modern era cannot easily be simplified. It was a time of great diversity and depth of thought, when individuals took hold of their faith for themselves. King's anthology successfully re-creates this atmosphere.

ANGELA RANSON

University of York

\title{
Lay, Jenna.
}

Beyond the Cloister: Catholic Englishwomen and Early Modern Literary Culture.

Philadelphia: University of Pennsylvania Press, 2016. Pp. ix, 243. ISBN 978-08122-4838-8 (hardcover) US\$65.

In her study of early modern Catholic Englishwomen, Jenna Lay embarks on a reexamination of English literary history, one that takes as its premise the critical need to interrogate the place of both nuns and recusant Catholic women in post-Reformation literary culture. Lay argues that while the "significance" of early modern Catholic women was often "effaced in their own time and has been mostly forgotten in ours" (16), they nonetheless made substantial contributions to political, religious, and literary discourses of the era. Beyond the Cloister covers extensive ground; considering a variety of authors and texts from approximately the 1590s to the 1660s, Lay takes a number of approaches in demonstrating the importance of Catholic women to early modern literary culture. She shows how Catholic women exist as persistent "objects of representation or erasure" (18) for canonical Protestant authors, examines Catholic Englishwomen's navigations of various literary and narrative techniques, and suggests that under-explored works by Catholic women can sometimes shed light on challenging canonical texts.

Although Lay's four chapters are often in conversation with one another, each takes as its focus a specific issue that revolves around representations of Catholic women. The first chapter investigates the representational difficulties 
posed by women who existed outside the bounds of Protestant marriage-both women who indefinitely retained their virginity, especially for religious reasons, and Catholic wives who, because of coverture, were often left unpunished for recusancy. Attention is given to Spenser's The Faerie Queene, Marlowe's Hero and Leander, Shakespeare's Measure for Measure, and John Mush's "A True Report of the Life and Martyrdom of Mrs. Margaret Clitherow."

In chapter 2, Lay contends that texts such as John Webster's The Duchess of Malfi and Thomas Robinson's The Anatomy of the English Nunnery at Lisbon "obscure Catholic women's contributions to literary culture" (19). In one of the most compelling sections of the book, Lay examines Robinson's pamphlet, which was written about the convent of Bridgettine nuns that relocated from Syon Abbey following the dissolution of the monasteries, alongside a written defense crafted by the nuns themselves. Lay argues that Robinson enacts an "erasure of female intellectual engagement" (81) by portraying the nuns as nothing more than victims of a confessor who alters religious texts in order to beguile and corrupt the women in his care; in their response, however, the nuns resist this elision through both the content of their manuscript, which refutes Robinson's allegations, and the intricate way in which their collective text is constructed.

In chapter 3, Lay considers representations of obedience in two very different texts. Beginning with Gertrude More's Spiritual Exercises, Lay shows how More not only carefully manoeuvres opposing demands for obedience, but also alludes to similar conflicts confronted by her great-great-grandfather, Thomas More. Lay then goes on to suggest that the pawns' plot of Thomas Middleton's A Game at Chess is most clearly and effectively read not as part of a political allegory, as the entire play is so often read, but rather, in light of texts such as More's, as a commentary on obedience and "the place and authority of female monastics" (92).

In the fourth chapter, Lay turns to an exploration of Catholic Englishwomen's literary communities. She argues that, against works such as Marvell's "Upon Appleton House," which portrays female literary communities as threats to marriage and then abolishes such communities, the letters of the Aston and Thimelby women show female communities to be "sites of complex engagement with questions of faith, love, and language" (142). Lay does find, however, that Margaret Cavendish's The Convent of Pleasure comes somewhat closer than 
Marvell's poem to portraying the potential inherent within Catholic women's literary communities.

Together, Lay's four chapters, as well as her introduction and epilogue, refute the obsolescence of Catholic women to early modern literary culture. Connections between texts and authors occasionally appear somewhat inconclusive, but this is, as Lay indicates herself during a discussion of Mary Champney(s), perhaps a result of the "omissions that have erased Catholic women from English literary history" (9). In fact, some of Lay's most interesting arguments involve just such cases, including the possibility that the nun Mary Champney, whose life is detailed within the anonymous The Life and Good End of Sister Marie, is actually the Mary Champneys raped by George Puttenham and then abandoned by him in Antwerp. Beyond the Cloister compellingly reveals the productivity of reading the lives and writings of Catholic Englishwomen and the need to take "alternative paths through literary history" (160).

KARALYN DOKURNO

University of Manitoba

\section{Nejeschleba, Tomáš, and Paul Richard Blum, eds.} Francesco Patrizi: Philosopher of the Renaissance.

Proceedings from The Centre for Renaissance Texts Conference (24-26 April 2014). Olomouc (CZ): Centre for Renaissance Texts / Univerzita Palackého v Olomouici, 2014. Pp. 384. ISBN 978-80-244-4428-4 (paperback) n.p.

This collection of articles on Francesco Patrizi da Cherso (1529-97) opens with a solid contribution by Maria Muccillo that contextualizes the man's character and culture by analyzing his studies, philosophy, way of thinking, and works. Muccillo points out how, in his university years in Padua, Patrizi moved from Aristotelianism and the study of medicine to philosophy. Using the didactic method he had learned from the humanist doctor Giovanni Battista dal Monte (1498-1551), Patrizi organized knowledge in a logical-deductive manner that led to his Città felice (1551) and his later works, Dialoghi dell'historia (1560) and Della Retorica dialoghi dieci (1562), where he reaches back to Lorenzo Valla (ca. 1407-57) in order to "bring order and light to the writings of the ancient historians" (22; my translation). Patrizi uses the same method a few 